\title{
Patient Satisfaction in the Spanish National Health Service: Partial Least Squares Structural Equation Modeling
}

\author{
María del Carmen Valls Martínez *(-) and Alicia Ramírez-Orellana \\ Department of Economics and Business, University of Almería, 04120 Almeria, Spain; aramirez@ual.es \\ * Correspondence: mcvalls@ual.es; Tel.: +34-950-01-55-35
}

Received: 14 November 2019; Accepted: 2 December 2019; Published: 4 December 2019

\begin{abstract}
The aim of this article was to determine which key indicators influence patient satisfaction with the Spanish NHS to provide useful information for policy decision-making. A total of 33 variables for each of the 17 Spanish autonomous communities were collected from the statistical portal of the Spanish Ministry of Health, Social Services, and Equality between 2005 and 2016. A cross-sectional study was applied using Partial Least Squares to a Structural Equation Model (PLS-SEM). The influence of expenditures, resource allocation, and safety were hypothesized about patient satisfaction. Gross Domestic Product (GDP) and life expectancy were used as control variables. Moreover, the influence of resource allocation on use was tested. The model explained $57.1 \%$ of patient satisfaction with the Spanish NHS. It was positively influenced mainly by resource allocation and expenditures, followed by safety and life expectancy. Additionally, resources directly influenced the level of use. The number of hospital beds, hemodialysis equipment, rate of adverse drug reactions, and expenditure positively influenced patient satisfaction. In contrast, the number of posts in day hospitals, the hospital infection rate, and the percentage of pharmacy spending negatively influenced patient satisfaction.
\end{abstract}

Keywords: National Health Service; patient satisfaction; health policy; quality of healthcare; partial least squares structural equation modeling (PLS-SEM)

\section{Introduction}

An excellent healthcare service contributes to improving the health of population in a specific country by increasing the expectancy of life of its citizens, promoting its social equity, and enhancing the efficiency of its economy [1]. The main aim of National Health Service (NHS) is to achieve a healthier population, that is, to improve citizens' quality of daily life and health. This implies an essential challenge to the health managers, who have to face an increasingly demanding population and the rising cost of medical technology and resources that are not only limited and scarce, but also reduced as a consequence of the economic crisis. The system is complex and there are many factors to consider, so its management is difficult, and this difficulty is increased by the limited availability of data [2].

Indeed, in recent years, the economic crisis has led governments to reduce investment in public services, including healthcare service, while citizens are increasingly interested in the management and quality of the services they receive, the cost of which is paid through taxes. Therefore, the decrease of the budget in the provision of certain services can affect citizen satisfaction with the NHS [3].

Since the time of Hippocrates, there has been concern regarding the quality of healthcare [4] because quality is vital for patient satisfaction and the success of the health industry [5]. A higher quality is identified by greater patient satisfaction [6,7]. In fact, healthcare is a sector where low quality 
has serious consequences [8], so customers (patients) are more intolerant of poor service quality than in other sectors [9]. Service quality is an important and increasing issue of research in management, especially health service quality, which is more important than other services [10].

According to Numbeo [11], in mid-2019, the healthcare index for countries ranked from 86.89 in Taiwan to 39.35 in Morocco, out of the 89 countries considered (Table 1). Europe ranked from 79.46 in Austria to 47.62 in Hungary. Spain, with an index of 78.42, was the third country in Europe and the seventh in the world to be ranked in a high position, which is a positive sign for the Spanish NHS.

Table 1. Healthcare index by country.

\begin{tabular}{ccc}
\hline Region & Analyzed Countries & Range \\
\hline World & 89 & $86.69-39.35$ \\
Africa & 7 & $63.27-40.17$ \\
America & 15 & $71.27-40.17$ \\
Asia & 30 & $86.89-41.32]$ \\
Europe & 35 & $79.46-47.62$ \\
Oceania & 2 & $76.82-73.71$ \\
\hline
\end{tabular}

The Euro Health Consumer Index in 2018 assigned 19th place to Spain among 35 European countries and affirmed that medical excellence can be found in many Spanish places. It recognized that Spain has a large regional variation and the Spanish rely on private care for real excellence. The Spanish Constitution, the main law in the country, establishes the right to health protection and healthcare for all citizens. The Spanish NHS is publicly funded and it is characterized by the universality and gratuity of health services at the time of use; however, there exists, in the country, a parallel private health system, which is optional and complementary to public service.

In 1954, Koos [12] said that patients' opinions about the healthcare received had to be taken into account and consideration of the patients' views as a measure for healthcare outcome was advanced by Donabedian [13]. The concept of perceived service quality, however, was first proposed by Gronroos in 1982 [14]. Thus, the idea of identifying quality with the effectiveness of medical treatments was extended to include patient satisfaction as a requirement for good clinical practice. This is how healthcare is considered by the European Foundation Quality Management (EFQM) and the International Organization for Standardization (ISO) [15]. The EFQM model considers that patient satisfaction represents $20 \%$ of the total value [16]. Today, patient satisfaction is thought to be the best indicator in the evaluation and improvement of quality in healthcare services [17-19]. Indeed, Busse et al. [20] analyzed how the definitions of healthcare quality have evolved from the exclusive consideration of health professionals' opinion to the consideration of preferences and views of patients.

Patient satisfaction is a useful instrument to value the healthcare process since it provides information about the perceived quality and therefore, can be incorporated in a program of valuation and quality improvement [21,22]. The citizens' opinions offer the necessary information to adequately manage health resources [23]. For this reason, patient satisfaction has been used to measure the performance of the NHS [24], since it is an excellent indicator of its quality and effectiveness [4]. A high degree of patient satisfaction is usually linked to advanced compliance of the treatments and therefore, it is a signal of health success [1].

Patient satisfaction is a consequence of the interaction between the needs, expectations, and experiences of patients [25]. If the result of healthcare is measured by patient satisfaction with the result achieved, the NHS will be able to satisfy not only the patient's needs but also their expectations, since satisfaction is understood as the difference between the patient's expectations and his degree of perception of the public service [26-29]. When the perceived performance matches or beats the expectations, the service is considered satisfactory. If it does not, the patient is dissatisfied [30]. A previous research affirmed that an unsatisfactory experience influences patient satisfaction more than a good experience [31]. 
In recent decades, studies about patient satisfaction have been generalized, but their use as a management tool is still unusual [3] because they used to focus more on health personnel (such as physicians and nurses). Without a doubt, a better understanding of how the satisfaction is structured can provide useful knowledge to the managers of health services to implement proper measures, which stimulate the improvement of the services [32]. The decreasing financial resources caused by worldwide crisis and population aging require strategies to improve the service quality in order to maximize patient satisfaction with the lowest possible costs $[8,33,34]$. Since patient satisfaction allows the evaluation of NHS quality, the development of this type of studies is a measure of responsibility because they provide information on the policies to be implemented and on political programs for healthcare $[9,35]$. The analysis of patient satisfaction must provide information to healthcare professionals as well as to managers and administrators of the NHS.

Accordingly, the aim of this study was to determine which indicators, among those with available information, positively or negatively influence patient satisfaction in the Spanish NHS, and can provide useful information to system managers. This paper makes the following contributions to the existing literature. First, it provides empirical evidence on the Spanish NHS, which has been scarcely analyzed in this context. Moreover, this paper considers a wide time interval (2005-2016). Second, we used a methodology scarcely used in this sector to date and with this purpose. Third, the study analyzed the influence of expenditures, resources allocation, and safety on patient satisfaction through a wide array of variables, which led us to interesting conclusions.

\section{Literature Background and Hypotheses}

Patient satisfaction is the result of multiple factors, so it is a complex and multidimensional construct. Therefore, its measurement is difficult, and studies about patient satisfaction are heterogeneous, that is, there is a lack of standardization in the methods used to measure patient satisfaction [36-38].

There exists an array of questionnaires and scales to measure satisfaction in the service sector. The most widely used scale is SERVQUAL [39,40], developed by Parasuraman et al. [26]. SERVQUAL considers five dimensions of service quality [28,41]: tangibles, assurance, empathy, reliability, and responsiveness. The primary variable that can be controlled by political managers is tangibility or, in other words, resource allocation, which was considered in our study.

Items related to human quality are highly significant to measure patient satisfaction and they have frequently been used in previous studies [42,43]. This kind of variable is not directly controlled by policy makers and therefore, it is not included in public studies, which explains the absence of available public data. In recent years, satisfaction related to a physician's gender has also been studied [44]. In this respect, we considered that managers should not make gender distinctions, but consider a doctor's ability regardless of gender.

Since physicians are the most visible element of the healthcare service, it is important to determine patient satisfaction related to family and specialist doctors. Family doctors used to be on the upper levels of satisfaction $[45,46]$ because they are closer to the patients. This indicator leads to greater satisfaction, which, in turn, implies greater compliance and adherence to treatment. This circumstance is the main objective of a healthcare service [4]. Currently, it is not enough that the physician provides competent medical care [47] since patient-centered communication increases satisfaction [48]. For this reason, although patients remember less than half of the information supplied by their doctors [49], the quality and quantity of information received is essential for decision-making by patients [50]. Therefore, the information received in consultation with a specialist doctor is an essential key to patient satisfaction.

The previous literature found a positive relationship between patient satisfaction and healthcare expenditure, in such a way that a higher per capita expenditure in the NHS was associated with higher patient satisfaction $[15,51]$. In Spain, where health competencies are assigned to the autonomous communities and therefore, budget allocation is uneven across the country, differences in patient 
satisfaction have been observed [1]. Specifically, the north of the country, where the wealthiest communities reside, showed higher levels of satisfaction than the poor communities located in the south [4].

The most widespread variable in studies on patient satisfaction is resource allocation [3,52]. It generally involves infrastructure [30,32], availability of material and equipment [29,53], tangibility [33], or physical facilities [2]. Medical staff is also included in this concept when used in a broad sense [15]. All the analyzed studies found that a more significant resource provision leads to higher patient satisfaction.

In 2004, the World Health Organization officially authorized the World Alliance for Patient Safety. The intention was to promote patient safety worldwide. This medium reduces the adverse health consequences of unsafe medical care because there are too many safety claims and therefore, much to improve in this area [54]. Security is positively related to quality [30,33]. As a consequence, higher security increases patient satisfaction $[2,52,55,56]$.

The level of use, often referred to as access [2], is generally related to patient satisfaction [3,21,52]. Nevertheless, the direction of the relationship between the two variables is not always the same, since there is a positive association in some cases and negative in others. The main reason for this is the variable of use considered. For example, the longer the length of the hospital stay, the lower the satisfaction [57]. Analog behavior has the number of surgical interventions; however, the outpatient surgery percentage of the number of hospital admissions shows a positive relationship with patient satisfaction [58]. The inverse relationship that links both variables can be explained by considering the satisfaction as the result of the need to continue using services that previously did not meet expectations; that is, it is the result of unsatisfactory service [36].

Gross domestic product (GDP) per capita has been included in some prior studies. In this sense, Europe has been found to have greater patient satisfaction in people with higher incomes $[15,59]$. Nevertheless, prior research conducted in Spain established that GDP per capita is not related to patient satisfaction [1].

The literature has considered personal variables, such as age, gender, and health condition [60]. The results are not conclusive, especially with respect to age and gender, which have been found not significant in most cases $[1,55]$. On the contrary, there is consensus with respect to a health condition [53,59], which has been found to be significant, by considering that the most satisfied patients had a greater mortality risk [51]. In our study, life expectancy at birth was the variable analyzed, since we understood that this variable includes, in some way, the three mentioned variables.

Based on the discussed literature, the following hypotheses emerged to provide the scope and depth of this study:

Hypothesis 1 (H1). Expenditures positively influence patient satisfaction.

Hypothesis 2 (H2). Expenditures positively influence resource allocation.

Hypothesis 3 (H3). Resource allocation positively influences patient satisfaction.

Hypothesis 4 (H4). Safety positively influences patient satisfaction.

Hypothesis 5 (H5). Resource allocation positively influences the level of use of resources.

Hypothesis 6 (H6). GDP per capita positively influences patient satisfaction.

Hypothesis 7 (H7). Life expectancy at birth positively influences patient satisfaction.

Hypothesis 8 (H8). Resource allocation mediates the relationship between expenditures and patient satisfaction. 


\section{Materials and Methods}

\subsection{Data and Sample}

We conducted a study using data from the perception of Spanish patients. The data of the variables were obtained from the publication made by the Spanish Ministry of Health, Social Services, and Equality (MHSE). This institution has a statistical portal on the means of each autonomous community of the key indicators of the national health system. We used data from 2005 to 2016 ; hence, the study encompassed 12 years. The data were provided by the information system of the NHS, the National Statistics Institute, and the Spanish Agency of Medicines and Health Products. The maintenance of the indicator set corresponded to the Health Information Institute. The public had no detailed information about the questionnaire, the participation, and so on. Thus, in this study, we only had access to the data, but not to its gathering process.

The European Core Health Indicators (ECHI) model was adapted to the characteristics of the Spanish national health system and its information system and strategic priorities. Other national (Andalusia) and international (Organization for Economic Co-operation and Development, World Health Organization) models were also taken into account, but compatibility with the ECHI indicators was always kept.

Table 2 provides a summary of all the variables and the indicators included in the model, their acronyms, and the data source used. Table 3 shows the mean and standard deviation in 2005 and 2016 for each variable and the variation in the total period.

Previous studies [61-63] showed how structural equation modeling (SEM) could become an indispensable tool for managers, policymakers, and regulators in the healthcare sector. Our data came from indexes, as mentioned above, and were contained in a database; therefore, they were secondary data. The primary constructs included in our research model met the requirements of a composite measurement model [64,65].

In this article, we used a partial least square (PLS-SEM) composite scheme to represent the total variance of the variables [66] for different reasons. In particular, PLS-SEM was an adequate model in the case of inclusion of archival information or secondary data [67]. Moreover, PLS composite scheme mode B estimation takes into account the collinearity between the items, giving less weight to the most redundant indicators. Furthermore, as Becker et al [68] suggested, we chose indicators as composite mode $\mathrm{B}$, except patient satisfaction, because the estimation of the weights optimizes $R^{2}$ in-sample prediction. We chose composite mode A for patient satisfaction because of collinearity between the indicators [68,69]. All the issues, as mentioned above, summarized the statistical characteristics of the data available in this research.

Figure 1 depicts the theoretical model proposed in our study. As Figure 1 shows, we examined the relationship between expenditures, resource allocation, and safety over patient satisfaction (Hypotheses 1,3 , and 4). In addition, we analyzed the influences of expenditures on resource allocation (Hypothesis 2), and resource allocation on the level of the use of resources (Hypothesis 5). The influence of the control variables, GDP per capita and life expectancy, was studied on the latent variable, patient satisfaction (Hypotheses 6 and 7). Finally, a mediation effect of resource allocation was analyzed through Hypothesis 8. Expenditures have a direct effect on patient satisfaction, but also an indirect effect through resource allocation. The previous literature has exposed similar effects [70,71]. In our case, we postulated a positive mediation effect and that, at the same time, the simple and direct effects reflected in $\mathrm{H} 2$ and $\mathrm{H} 3$ are positive. It would be a problem if the hypotheses contradicted each other. 
Table 2. Data description and source.

\begin{tabular}{|c|c|c|}
\hline Composites & Indicators & Description \\
\hline \multirow{3}{*}{$\begin{array}{l}\text { Patient satisfaction } \\
\quad(\text { mode A) }\end{array}$} & PS1 & $\begin{array}{l}\text { Degree of satisfaction of citizens with the functioning of the } \\
\text { public health system. }\end{array}$ \\
\hline & PS2 & $\begin{array}{l}\text { Degree of citizen satisfaction with knowledge of the history } \\
\text { and monitoring of their health problems by the family } \\
\text { doctor and pediatrician. }\end{array}$ \\
\hline & PS3 & $\begin{array}{l}\text { Degree of satisfaction of the citizen with the information } \\
\text { received in consultation with a specialist doctor about his } \\
\text { health problem. }\end{array}$ \\
\hline \multirow{8}{*}{ Expenditures (mode B) } & EX1 & $\begin{array}{l}\text { Territorialized public health expenditure, per protected } \\
\text { inhabitant. }\end{array}$ \\
\hline & $\mathrm{EX} 2 *$ & Percentage of the cost of specialized care services. \\
\hline & EX3 & Percentage of health expenditure in primary care. \\
\hline & EX4 & Percentage of spending dedicated to concerts. \\
\hline & EX5 & Percentage of expenditure on intermediate consumption. \\
\hline & EX6 & Percentage of pharmacy spending. \\
\hline & EX7 * & Percentage of staff compensation expense. \\
\hline & EX8 & $\begin{array}{l}\text { Percentage of health expenditure destined to training } \\
\text { residents. }\end{array}$ \\
\hline \multirow{8}{*}{ Resources (mode B) } & RE1 & $\begin{array}{l}\text { Number of medical staff in specialized care for } 1000 \\
\text { inhabitants. }\end{array}$ \\
\hline & RE2 & Number of hospital beds in operation per 1000 inhabitants. \\
\hline & RE3 * & Number of operating theaters for 100,000 inhabitants. \\
\hline & RE4 & Number of posts in day hospitals per 1000 inhabitants. \\
\hline & RE5 * & $\begin{array}{l}\text { Number of computerized axial tomography (CT) equipment } \\
\text { in operation per } 100,000 \text { inhabitants. }\end{array}$ \\
\hline & RE6 & $\begin{array}{l}\text { Number of hemodialysis equipment in operation per } 100,000 \\
\text { inhabitants. }\end{array}$ \\
\hline & RE7 & $\begin{array}{l}\text { Number of hemodynamic equipment in operation per } \\
100,000 \text { inhabitants. }\end{array}$ \\
\hline & RE8 & $\begin{array}{l}\text { Number of nuclear magnetic resonance (NMR) equipment } \\
\text { per } 100,000 \text { inhabitants. }\end{array}$ \\
\hline \multirow{8}{*}{ Level of use (mode B) } & LU1 * & \multirow{8}{*}{$\begin{array}{l}\text { Frequency of hospital admissions per } 1000 \text { inhabitants/year. } \\
\text { Outpatient surgery percentage. } \\
\text { Surgical interventions rate per } 1000 \text { inhabitants/year. } \\
\text { Rate of use of CT per } 1000 \text { inhabitants/year. } \\
\text { Rate of use of hemodialysis per } 1000 \text { inhabitants/year. } \\
\text { Rate of use of hemodynamics per } 1000 \text { inhabitants/year. } \\
\text { Rate of use of NMR for } 1000 \text { inhabitants/year. } \\
\text { Frequency in specialized care consultations per } 1000 \\
\text { inhabitants/year. }\end{array}$} \\
\hline & LU2 & \\
\hline & LU3 * & \\
\hline & LU4 * & \\
\hline & LU5 & \\
\hline & LU6 & \\
\hline & LU7 & \\
\hline & LU8 & \\
\hline \multirow{4}{*}{ Safety (mode B) } & SA1 & \multirow{4}{*}{$\begin{array}{l}\text { Hospital infection rate. } \\
\text { Overall in-hospital mortality per } 100 \text { hospital discharges. } \\
\text { In-hospital mortality after surgical intervention per } 100 \\
\text { surgical discharges. } \\
\text { Reporting rate of adverse drug reactions. }\end{array}$} \\
\hline & SA2 & \\
\hline & SA3 * & \\
\hline & SA4 & \\
\hline $\begin{array}{l}\text { GDP per capita (control } \\
\text { variable) }\end{array}$ & GDP & Gross domestic product per capita. \\
\hline $\begin{array}{l}\text { Life expectancy (control } \\
\text { variable) }\end{array}$ & LE & Life expectancy at birth. \\
\hline
\end{tabular}

Source: Ministry of Health, Social Services, and Equality (MHSE), 2005-2016. * These indicators were not included in latent variables due to the multicollinearity criteria of PLS-SEM. 
Table 3. Mean, standard deviation, and variation in the period 2005-2016.

\begin{tabular}{|c|c|c|c|c|c|c|}
\hline Composites & Indicators & Mean 2005 & $\begin{array}{c}\text { Standard } \\
\text { Deviation } 2005\end{array}$ & Mean 2016 & $\begin{array}{c}\text { Standard } \\
\text { Deviation } 2016\end{array}$ & $\begin{array}{c}\text { Variation } \\
\text { 2005-2016 }\end{array}$ \\
\hline \multirow{3}{*}{$\begin{array}{c}\text { Patient } \\
\text { satisfaction }\end{array}$} & PS1 & 6.25 & 0.45 & 6.73 & 0.38 & 7.68 \\
\hline & PS2 & 7.14 & 0.37 & 7.72 & 0.25 & 8.12 \\
\hline & PS3 & 7.06 & 0.48 & 7.31 & 0.35 & 3.54 \\
\hline \multirow{8}{*}{ Expenditures } & EX1 & 1157.56 & 80.89 & 1462.79 & 131.19 & 26.37 \\
\hline & EX2 & 56.66 & 3.17 & 63.55 & 3.33 & 12.16 \\
\hline & EX3 & 14.31 & 2.01 & 14.07 & 1.74 & -1.68 \\
\hline & EX4 & 7.53 & 7.51 & 7.38 & 5.09 & -1.99 \\
\hline & EX5 & 19.22 & 2.36 & 25.95 & 3.23 & 35.02 \\
\hline & EX6 & 22.97 & 2.77 & 16.83 & 1.99 & -26.73 \\
\hline & EX7 & 44.72 & 5.96 & 47.74 & 4.42 & 6.75 \\
\hline & EX8 & 1.20 & 0.36 & 1.70 & 0.40 & 41.67 \\
\hline \multirow{8}{*}{ Resources } & RE1 & 90.78 & 6.58 & 92.22 & 6.10 & 1.59 \\
\hline & RE2 & 73.94 & 10.84 & 79.47 & 9.85 & 7.48 \\
\hline & RE3 & 67.88 & 8.98 & 73.01 & 9.41 & 7.56 \\
\hline & RE4 & 78.90 & 19.92 & 87.06 & 10.84 & 10.34 \\
\hline & RE5 & 67.90 & 12.03 & 73.03 & 11.24 & 7.56 \\
\hline & RE6 & 84.21 & 15.51 & 90.44 & 11.39 & 7.40 \\
\hline & RE7 & 61.58 & 22.87 & 66.11 & 16.45 & 7.36 \\
\hline & RE8 & 46.60 & 16.35 & 56.05 & 13.43 & 20.28 \\
\hline \multirow{8}{*}{ Level of use } & LU1 & 76.61 & 11.34 & 79.31 & 10.98 & 3.52 \\
\hline & LU2 & 35.19 & 7.54 & 43.07 & 6.24 & 22.39 \\
\hline & LU3 & 70.01 & 10.86 & 72.76 & 10.87 & 3.93 \\
\hline & LU4 & 83.68 & 10.69 & 85.29 & 9.80 & 1.92 \\
\hline & LU5 & 78.67 & 25.07 & 89.23 & 14.61 & 13.42 \\
\hline & LU6 & 74.73 & 24.94 & 86.61 & 12.61 & 15.90 \\
\hline & LU7 & 15.43 & 3.15 & 39.11 & 15.67 & 153.47 \\
\hline & LU8 & 1459.08 & 232.05 & 1722.69 & 242.03 & 18.07 \\
\hline \multirow{4}{*}{ Safety } & SA1 & 1.19 & 0.32 & 1.05 & 0.26 & -11.76 \\
\hline & SA2 & 4.13 & 0.46 & 4.78 & 0.61 & 15.74 \\
\hline & SA3 & 1.77 & 0.30 & 1.72 & 0.25 & -2.82 \\
\hline & SA4 & 243.53 & 174.71 & 588.37 & 418.93 & 141.60 \\
\hline GDP per capita & GDP & 20.99 & 4.01 & 23.50 & 4.96 & 11.96 \\
\hline Life expectancy & LE & 80.45 & 0.84 & 83.49 & 0.78 & 3.78 \\
\hline
\end{tabular}

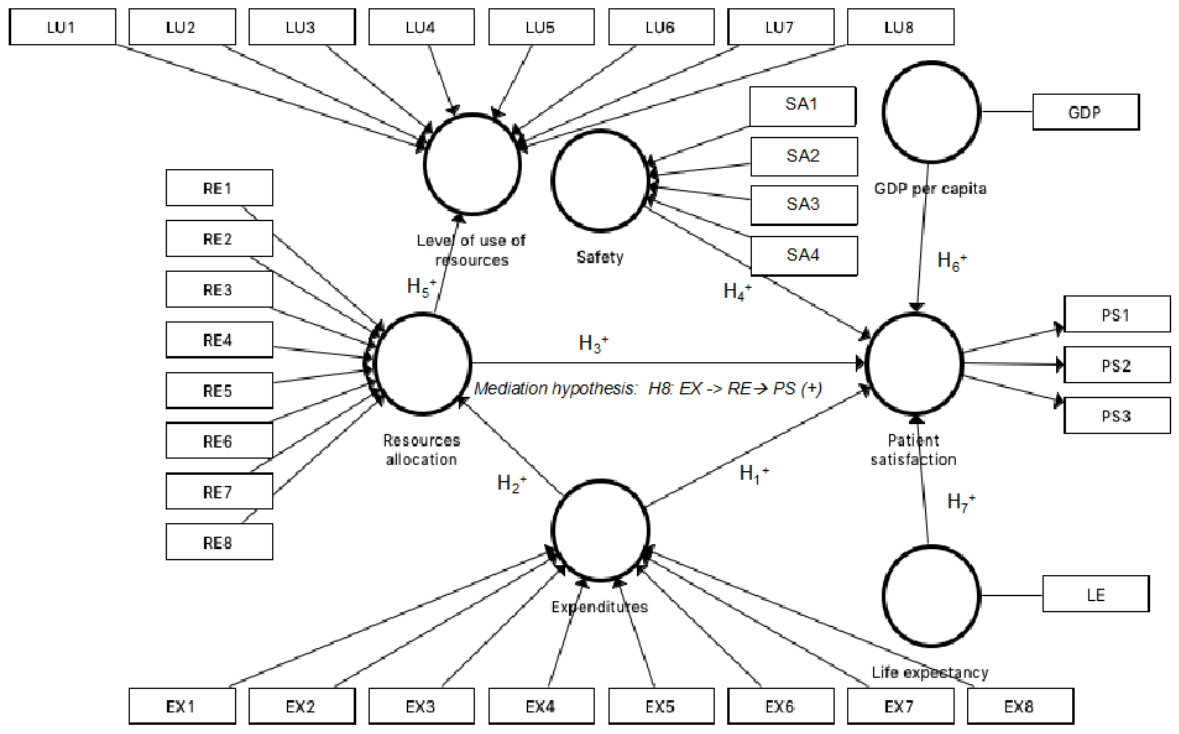

Figure 1. Research model and hypotheses. 


\subsection{Measurement Variables}

The selected variables were based on the secondary data from MHSE, which, in turn, had been based on the conceptual model suggested by ECHI. All the variables associated with each construct are shown in Table 2. In particular, the following constructs were part of our model:

Patient satisfaction: The dependent variable was measured by the endogenous variable, patient satisfaction. One of the critical components of quality is the ability of the system to respond to patient preferences, attitudes, and expectations. Patient-centered care is defined as that which establishes an adequate interrelation between professionals and patients to ensure that the decisions made regarding their care process take into account their needs, desires, and preferences. Analogous to the business model of customer satisfaction, patient satisfaction could serve as a patient-centered focus for increasing the care experience in a national health system. There are three indicators of patient satisfaction: (i) degree of satisfaction of the citizen with the information received in the consultation of the specialist doctor about their health problem, (ii) degree of citizen satisfaction with knowledge of the history and monitoring of their health problems by the family doctor and pediatrician, and (iii) degree of satisfaction of citizens with the functioning of the public health system. These indicators were measured by a Likert scale ranging from 1 to 10 . Patient satisfaction reflects the patient's perception of the entire care process and the improvement of satisfaction metrics is within the power of an institution.

Expenditures: One of the three exogenous variables was expenditures. It is defined as the disbursement of goods and services intended to preserve, maintain, recover, or improve the health level of a population. When there are limitations in the budget of the healthcare system, the cost-effectiveness analysis can guide policymakers in resource allocation decisions. All the expenditure variables considered refer to the public sector; in other words, they were public budget data.

Resource allocation: The second exogenous variable was resource allocation. A high-quality health benefit requires the availability of sufficient resources to meet individual and population needs. The capacity of the system refers to economic resources, infrastructure, equipment, human resources, medical devices, and medicines.

Safety: The third exogenous construct refers to the process by which the healthcare system provides safe patient care. It involves minimizing the unnecessary risk of harm to the patient. Healthcare that promotes patient safety in the provision of care implies risk management; declaration, analysis, and monitoring of incidents; and implementation of solutions to minimize incidents.

Level of use: This endogenous variable is defined as the use made by citizens of health services. Resource allocation may, in turn, determine the level of use that patients make of such resources.

Control variables: Two control variables were studied (GDP per capita and life expectancy at birth) to research their impact on the endogenous variable, patient satisfaction.

\subsection{Statistical Procedure}

The structural equation model was analyzed in a two-step process [72]. We first described the results for the measurement model, which specifies the relationships between constructs and their indicators, before those relating to the structural model, which contains the relationships between constructs or the hypotheses of the model.

(i) Analysis of the measurement model.

(ii) Analysis of the structural model.

This sequence ensured that the measurement scales were valid and reliable before attempting to reach conclusions about the hypotheses included in the structural model [73]. This study applied Smart-PLS 3.2.7 software (SmartPLS GmbH, Bönningstedt, Germany) [74]. 


\section{Results}

This section details the results obtained for the proposed research model.

\subsection{Measurement Model}

\subsubsection{Composite Mode A}

The composite measurement model in mode A (patient satisfaction) was assessed in terms of individual item reliability, construct reliability, convergent validity, and discriminant validity.

First, the individual item reliability was analyzed through the loadings. As Figure 2 illustrates, the loadings exceeded the cut-off value of 0.708. Second, Cronbach's alpha, Dijkstra-Henseler's rho coefficients, and composite reliability were used to evaluate construct reliability. As Table 4 shows, the construct exceeded the recommended cut-off value of 0.7 for these three measurements. Third, convergent validity was proven since the average variance extracted (AVE) for the construct was higher than 0.5 . Table 4 shows that the measurement model was satisfactory concerning the above criteria.

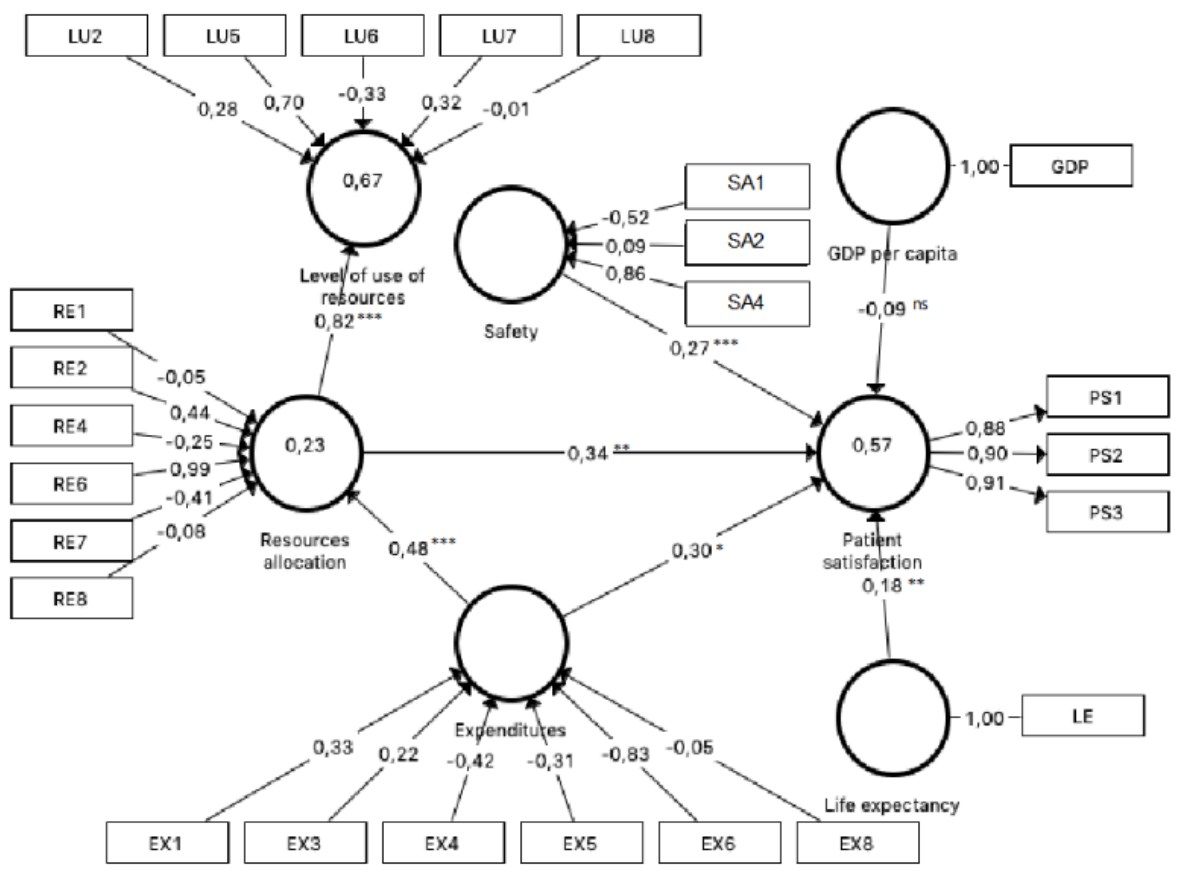

Figure 2. ${ }^{*} p<0.05 ;{ }^{* *} p<0.01 ; * * *<0.001$; ${ }^{* *}$ not significant. Whole model results.

Table 4. Measurement validation.

\begin{tabular}{ccccc}
\hline Composite $^{1}$ & Cronbach's Alpha & Dijkstra-Henseler's Rho & $\begin{array}{c}\text { Composite } \\
\text { Reliability (CR) }\end{array}$ & $\begin{array}{c}\text { Average Variance } \\
\text { Extracted (AVE) }\end{array}$ \\
\hline Patient satisfaction & 0.877 & 0.878 & 0.924 & 0.803 \\
\hline \multicolumn{4}{c}{${ }^{1}$ Patient satisfaction was measured as a mode A composite. }
\end{tabular}

Table 5 presents the results for discriminant validity through the Heterotrait-Monotrait ratio of correlations (HTMT) inference. All the constructs reached discriminant validity because no confidence interval contained the value of zero. This circumstance meant that each variable was different from the others [75]. 
Table 5. HTMT inference.

\begin{tabular}{lcccc}
\hline HTMT Inference * & Original Sample & Sample Mean & $\mathbf{5 . 0 \%}$ & $\mathbf{9 5 . 0 \%}$ \\
\hline Life expectancy $\rightarrow$ GDP per capita & 0.478 & 0.477 & 0.388 & 0.558 \\
Patient satisfaction $\rightarrow$ GDP per capita & 0.152 & 0.170 & 0.119 & 0.243 \\
Patient satisfaction $\rightarrow$ Life expectancy & 0.500 & 0.499 & 0.394 & 0.598 \\
\hline * Significance, 95\% bias-corrected confidence interval performed by a bootstrapping procedure with 10,000 \\
replications.
\end{tabular}

The data examined above in the measurement model showed that the measures of the construct, patient satisfaction, were reliable and valid.

\subsubsection{Composite Mode B}

The composite measurement model in mode B was assessed in terms of collinearity among indicators, significance, and the relevance of outer weights.

First, it carried out a process of discarding indicators, which was performed when the indicator exceeded the value of variance impact factor $(\mathrm{VIF}=3)$. As a result of this process, only the indicators shown in Table 2 remained without collinearity.

Second, the relevance of weights was analyzed. Figure 2 shows the relevance of the indicators within their construct. Thus, for the latent variable, expenditures, the items more positively relevant were EX1 (territorialized public health expenditure per protected inhabitant) and EX3 (percentage of health expenditure in primary care). In addition, EX4 (percentage of spending dedicated to concerts), EX5 (percentage of expenditure on intermediate consumption), and EX6 (percentage of pharmacy spending) presented negative relevance.

Concerning resource allocation, the items more positively relevant were RE6 (number of hemodialysis equipment in operation per 100,000 inhabitants) and RE2 (Number of the hospital beds in operation per 1000 inhabitants). On the other hand, the items that presented negative relevance were RE4 (number of posts in day hospitals per 1000 inhabitants) and RE7 (number of hemodynamic equipment in operation per 100,000 inhabitants).

The most positively relevant item for safety was SE4 (reporting rate of adverse drug reactions). Moreover, SE1 (hospital infection rate) showed negative relevance. About the level of use, the items more positively relevant were LU5 (rate of use of hemodialysis per 1000 inhabitants/year), LU7 (rate of use of NMR for 1000 inhabitants/year), and LU2 (outpatient surgery percentage). The item presenting a negative influence was LU6 (rate of use of hemodynamics per 1000 inhabitants/year).

Finally, to assess significance, one can start bootstrapping with 10,000 sub-samples in order to check whether outer weights are significantly different from zero, that is, the recommended minimum by Hair et al. [76]. Since the weights provide information about their contribution, they can be ranked regarding their respective composite [77]. Indicators with a nonsignificant weight, but with significant loadings of 0.50 or higher, were considered relevant [72], which was the case for LU2 and LU7 (Table 6). 
Table 6. Significance of weights.

\begin{tabular}{cccccc}
\hline & Original Sample & $t$ & Loadings & Lo95 & Hi95 \\
\hline Expenditures & & & & & \\
EX1 & $0.332^{*}$ & 1.910 & 0.673 & {$[0.006 ;$} & $0.578]$ \\
EX3 & $0.221^{\mathrm{ns}}$ & 1.775 & 0.368 & -0.018 & 0.395 \\
EX4 & $-0.419^{\mathrm{ns}}$ & 1.642 & -0.261 & -0.652 & -0.113 \\
EX5 & $-0.309^{\mathrm{ns}}$ & 1.424 & 0.049 & -0.523 & 0.024 \\
EX6 & $-0.834^{*}$ & 1.971 & -0.733 & -1.082 & -0.350 \\
EX8 & $-0.051^{\mathrm{ns}}$ & 0.308 & 0.213 & -0.287 & 0.261 \\
Resource Allocation & & & & & \\
RE1 & $-0.054^{\mathrm{ns}}$ & 0.397 & 0.344 & -0.283 & 0.164 \\
RE2 & $0.440^{* *}$ & 2.421 & 0.390 & 0.119 & 0.584 \\
RE4 & $-0.248^{*}$ & 2.030 & 0.156 & -0.368 & -0.055 \\
RE6 & $0.990^{* *}$ & 2.725 & 0.871 & 0.661 & 1.116 \\
RE7 & $-0.412^{\mathrm{ns}}$ & 1.571 & -0.143 & -0.664 & -0.051 \\
RE8 & $-0.075^{\mathrm{ns}}$ & 0.342 & 0.463 & -0.423 & 0.294 \\
Safety & & & & & \\
SA1 & $-0.520^{* *}$ & 2.907 & -0.461 & -0.681 & -0.304 \\
SA2 & $0.092^{\mathrm{ns}}$ & 0.669 & 0.158 & -0.133 & 0.316 \\
SA4 & $0.865^{* * *}$ & 4.239 & 0.863 & 0.713 & 0.969 \\
Level of use & & & & & \\
LU2 & $0.276^{*}$ & 2.183 & 0.593 & $-0,024$ & 0.390 \\
LU5 & $0.695^{*}$ & 2.263 & 0.869 & 0,355 & 0.948 \\
LU6 & $-0.329^{\mathrm{ns}}$ & 1.261 & -0.161 & -0.639 & 0.058 \\
LU7 & $0.323^{*}$ & 1.710 & 0.564 & -0.062 & 0.555 \\
LU8 & $-0.007^{\mathrm{ns}}$ & 0.052 & 0.348 & -0.259 & 0.197 \\
\hline
\end{tabular}

${ }^{*} p<0.05 ;{ }^{* *} p<0.01 ;{ }^{* * *} p<0.001$; ${ }^{\text {ns }}$ not significant. Significance, $t$ statistic, and $95 \%$ bias-corrected confidence interval performed by a bootstrapping procedure with 10,000 replications.

\subsection{Structural Model}

Once it was verified that the measurements of the constructs were appropriate, the assessment of the structural model was conducted.

Path coefficients and their 10,000 resampling bootstrap significance levels are reported in Table 7 and Figure 2. In addition, Table 7 shows that constructs' VIF ranged from 1.000 to 1.700, suggesting that collinearity was not a problem. Moreover, this study assessed quality by checking that the overall predictive relevance of the model by $Q^{2}$ value was above zero. It suggested a good fit in model prediction.

Our results suggested that GDP per capita, as a control variable, had no significant impact on patient satisfaction, so $\mathrm{H} 6$ was rejected. Expenditures, resource allocation, and safety had a positive and significant impact on patient satisfaction $(p=0.020, p=0.002, p=0.000$, respectively), as well as life expectancy at birth ( $p=0.017)$; hence, H1, H3, H4, and H7 were supported. Furthermore, the direct effects between expenditures to resource allocation and resource allocation to the level of use had a positive and significant impact ( $p=0.000, p=0.000$, respectively); therefore, $\mathrm{H} 2$ and $\mathrm{H} 5$ were supported as well.

These results followed the mediation effect since the total effect of expenses on patient satisfaction can be addressed by adding direct and indirect effects. The mediation hypothesis (H8) was analyzed when the indirect effects were significant [78]. The indirect effect of expenditures on patient satisfaction through resource allocation was positive and significant $(p=0.007)$, supporting H8 (Table 7). Moreover, the direct effect was also significant, which indicated that the mediation effect was partial [79]; that is, expenses influenced patient satisfaction directly $(\mathrm{H1})$, but also indirectly through resource allocation. The value of Variance Accounted For (VAF) indicated that the mediated proportion was $35.2 \%$ of the total effect of expenditures on patient satisfaction (see the indirect effect in Table 7). 
The determination coefficient $\left(R^{2}\right)$ exceeded 0.1 for the endogenous latent variable [80], so the constructs had an acceptable quality of prediction power.

Table 7. Whole sample results.

\begin{tabular}{|c|c|c|c|c|c|c|c|}
\hline & Path & $t$ & $p$ & Lo95 & Hi95 & $f^{2}$ & VIF \\
\hline \multicolumn{8}{|l|}{ Direct effects } \\
\hline $\mathrm{EX} \rightarrow \mathrm{PS}$ & 0.303 * & 2.055 & 0.020 & 0.157 & 0.40 & 0.128 & 1.676 \\
\hline $\mathrm{RE} \rightarrow \mathrm{PS}$ & $0.338^{* *}$ & 2.947 & 0.002 & 0.125 & 0.423 & 0.198 & 1.342 \\
\hline $\mathrm{SA} \rightarrow \mathrm{PS}$ & $0.272^{* * *}$ & 3.370 & 0.000 & 0.184 & 0.355 & 0.151 & 1.146 \\
\hline $\mathrm{GDP} \rightarrow \mathrm{PS}$ & $-0.086^{\mathrm{ns}}$ & 0.956 & 0.170 & -0.246 & 0.051 & 0.013 & 1.347 \\
\hline $\mathrm{LE} \rightarrow \mathrm{PS}$ & 0.180 * & 2.112 & 0.017 & 0.051 & 0.330 & 0.044 & 1.700 \\
\hline \multicolumn{8}{|c|}{$R^{2}: 0.57 ; Q^{2}: 0.426$} \\
\hline $\mathrm{EX} \rightarrow \mathrm{RE}$ & $0.475^{* * *}$ & 3.734 & 0.000 & 0.349 & 0.672 & 0.292 & 1.000 \\
\hline \multicolumn{8}{|c|}{$R^{2}: 0.23$} \\
\hline $\mathrm{RE} \rightarrow \mathrm{LU}$ & $0.817^{* * *}$ & 21.662 & 0.000 & 0.768 & 0.892 & 2.003 & 1.000 \\
\hline \multicolumn{8}{|c|}{$R^{2}: 0.67$} \\
\hline Indirect effect & & & & & & VAF & \\
\hline $\mathrm{EX} \rightarrow \mathrm{RE} \rightarrow \mathrm{PS}$ & $0.161^{* *}$ & 2.450 & 0.007 & 0.065 & 0.223 & $35.2 \%$ & na \\
\hline
\end{tabular}

${ }^{*} p<0.05 ;{ }^{* *} p<0.01 ; * * * p<0.001 ;{ }^{\text {ns }}$ not significant. Significance, $t$ statistic, and $95 \%$ bias-corrected confidence interval performed by a bootstrapping procedure with 10,000 replications. VIF: Inner model variance inflation factor; VAF: variance accounted for.

\section{Discussion}

We analyzed 33 variables to identify indicators capable of influencing patient satisfaction in the Spanish context. To do that, partial least squares (PLS-SEM) was applied to data from 2005 to 2016. The influence of expenditures, resource allocation, and safety constructs on patient satisfaction was tested. Resource allocation showed a positive influence on the level of use construct. The number of hospital beds, hemodialysis equipment, rate of adverse drug reactions, and expenditures positively influenced patient satisfaction. In contrast, the number of posts in day hospitals, the hospital infection rate, and the percentage of pharmacy spending negatively influenced patient satisfaction. The control variable, life expectancy, positively influenced patient satisfaction, but GDP was not significant.

It is necessary to integrate patients' opinions into the management of NHS, and studies about satisfaction enable this to be done. In this sense, this work was carried out to provide useful information to NHS managers about some variables and their influence on patient satisfaction. This would allow the implementation of health policies to improve the perception of the provision of services by their users.

It is important to note that to date, the specialized literature has offered results aimed primarily at healthcare professionals (physicians and nursing staff, fundamentally), but studies aimed at administrators and managers of NHS are scarce. For this reason, the variables of this study did not refer to a specific patient (age, gender, etc.) and their relationship with professionals (politeness given by healthcare professionals, patient participation in decision-making, etc.). On the one hand, we used variables of investments and results of health practice. On the other hand, we determined an increase in the level of satisfaction by studying many variables simultaneously.

We wanted to indicate that patient satisfaction with both family doctors and specialist doctors was higher than patient satisfaction with the functioning of the NHS. Thus, physicians were located in the upper echelons of assessment, in line with previous studies $[45,46]$.

This research analyzed the influence of expenditures, resource allocation, and safety on patient satisfaction, as well as the resource allocation on the level of use of the Spanish NHS. The aim was to increase knowledge for managers and the government on how these three latent variables were perceived by patients to value their satisfaction. Moreover, we introduced two control variables: 
GDP per capita and life expectancy. The proposed model confirmed seven of the eight causal relationships established, which explained $57.1 \%$ of patient satisfaction. The two most influential variables were resource allocation and expenditures, with similar weights, followed by safety and, finally, life expectancy.

A positive effect of resource allocation on patient satisfaction was found, in line with previous studies, which established that resources, such as facilities, explain a critical part of satisfaction [15,30,32] widely. We observed that the number of hospital beds in operation had a decisive weight in the construct, while the number of posts in day hospitals had a negative influence. This fact implied that citizens preferred that their health problems be solved as in-patients instead of outpatients. Previous research found that satisfaction is higher in in-patients [51,59]. The trend in Spain is a shift from more expensive in-patient care toward outpatient care [81]. Therefore, this change should be sufficiently explained to patients with the aim of showing them the advantages of such care. The number of hemodialysis equipment was an important variable that influenced the latent variable. This equipment was vital for the survival of a part of the population, and we observed a significant difference between autonomous communities. In general, the wealthiest communities have a better provision of equipment, which explained the mediation effect of resource allocation between expenditures and patient satisfaction, since most impoverished communities showed the lowest satisfaction with the NHS $[1,4,51]$.

Expenditures were also found to exert a positive influence on patient satisfaction, but with a slightly lower weight than resource allocation. This relationship was in agreement with prior literature [51]. The territorialized public health expenditure per protected inhabitant exerted a direct influence on satisfaction, which is in line with the results reported by Pérez-Romero et al. [15]. The percentage of pharmacy spending presented an inverse relation with patient satisfaction; Valls and Abad [58] found a similar relationship. In this sense, it is interesting to highlight that higher expenses in drugs influence satisfaction positively only in patients over 65 years old [36], which explained why drug expense negatively influenced patient satisfaction.

Safety directly affected patient satisfaction, but to a lesser extent than the two constructs previously analyzed, which is in line with previous research $[2,52,56]$. Thus, more safety implied higher satisfaction, which implied that hospital safety was perceived as a fundamental indicator of patient satisfaction. We observed that the hospital infection rate negatively affected patient satisfaction, which is rational, and it is in concordance with the results of Valls and Abad [58]. If a higher rate of adverse drug reactions positively affects patient satisfaction, we must assume that the treatment and attention received by patients is adequate and, consequently, that they perceive technical competence as satisfactory. They feel that the NHS is functioning properly [36]. In fact, since 2005, the Spanish authorities have established measures intended to improve patient safety, such as awareness of medical staff and patients or safety research [81].

The results showed that resources and the level of use were positively related. We assumed that the influence of resource allocation on the level of use could be related to the demands of sanitary equipment according to the diseases of the citizens, although the goal of the NHS is to improve the service by reducing costs $[8,34]$. In Spain, some complex diagnostic and treatment procedures are limited, and patients have to suffer long waiting lists. In areas where resources are more considerable, patients have better care, such as, more hemodialysis and CT equipment available for use. We mentioned the important variations across regions in Spain. On the other hand, and after considering the overuse of many surgical procedures, the "Commitment for the Quality of the Scientific Societies in Spain" aims to reduce unnecessary surgical interventions through an array of "do not do" recommendations about specific health services [81].

Regarding control variables, we found that GDP per capita did not exert any influence on patient satisfaction, which is in line with recent research performed in the Spanish context [1]. In this vein, the literature is not conclusive since other authors found a positive influence [15]. On the contrary, life expectancy at birth directly affected patient satisfaction and therefore, patients with more life 
expectancy valued the NHS more positively. In Spain, the NHS is different across the country, since health competencies have been transferred to autonomous communities and, accordingly, the quality of NHS is not homogeneous in all the territories. Hence, health population and life expectancy were influenced $[8,30]$, which impact patient satisfaction. It was interesting to observe (Table 3) that patient satisfaction had increased in the period of 2005-2016, especially satisfaction with family doctors and pediatricians. Expenditures increased more than GDP. It is remarkable that expenditures for training residents experienced the greatest growth, while the percentage of pharmacy spending decreased. It is noticeable that Spain is containing drug spending through the entry of generics in the market; in fact, pharmacists must substitute the medicine prescribed by the cheapest generic. Regarding resources, we noticed that the increase was, in general, below the level of expenditures. In fact, health expenditure per capita in Spain was below the European Union average; for example, in 2015, Spain accounted for 9.2\% of GDP, while the EU was 9.9\% [81]. Finally, if we observe the level of use, we can highlight the increase in outpatient surgery percentage to above $22 \%$.

The research in this article provides outstanding data on patient satisfaction with the Spanish NHS. Relevant factors that affect the perception of public health by citizens were identified. These factors are the number of hospital beds in operation, positions in day hospitals, hemodialysis equipment, percentage of outpatient surgery, CT use rate, NMR use rate, adverse drug reaction rate, hospital infection rate, public health spending, and percentage of pharmacy expenditures.

The results derived from this research give useful evidence to NHS managers and they provide valid information to help in the design and implementation of health policies, which lead to an improvement in the quality of provided services and, therefore, to greater patient satisfaction, since the analyzed variables explained $57.1 \%$ of patient satisfaction.

The main limitation we found in this study was the availability of information. It would have been interesting to know the selection process of interviewed population in order to establish generalizations. Moreover, it would be convenient to have data on other variables, which could be considered in the analyses of patient satisfaction, such as social variables (education level, poverty rate, etc.), success rate of treatments received, and sex disaggregated data. We understand that the method would be more efficient if we had had access to all the patients' surveys instead of the mean values of the surveys, but unfortunately, such data are not at public disposal. Similar research is needed to analyze this subject in other national and or regional healthcare services and with other secondary data.

We consider that it is necessary to deepen this kind of study in the future since, so far, most of the research has been focused on localized studies (for example, in a particular hospital) and preferably oriented to health personnel (mainly, physicians and nurses). The lack of available data at the national level has led to a shortage of research based on patient satisfaction and aimed at the design, application, and valuation of global health policies.

\section{Conclusions}

Understanding the influence of the complex interaction between expenditures, resource allocation, and safety to patient satisfaction allows informed decision-making to improve public health in the Spanish system. Using the structural equation modeling approach, we developed a patient satisfaction model. It allows for an impact comparison of the antecedent variables and provides the public agencies and policymakers critical information on variables with which they can make informed decisions. In this vein, according to our results, the number of hospital beds in operation and hemodialysis equipment were proven to be positively associated with patient satisfaction in our model. Likewise, the posts in day hospitals showed a negative influence. In this sense, we suggest that more attention is needed on patient satisfaction, while promoting the shift from in-patient to day care settings. Moreover, hospital infections must be controlled and minimized. Regarding public health expenditure, greater effort in this sense indicated increased patient satisfaction. 
Author Contributions: Conceptualization, M.d.C.V.M.; methodology, A.R.-O.; validation, M.d.C.V.M.; formal analysis, A.R.-O.; resources, M.d.C.V.M.; writing-original draft preparation, Md.C.V.M. and A.R.-O.; writing—review and editing, M.d.C.V.M. and A.R.-O.; visualization, M.d.C.V.M.; supervision, M.d.C.V.M.

Funding: This research was funded by the Ministry of Economy and Competitiveness, grant number DER2016-76053-R.

Acknowledgments: The authors gratefully acknowledge financial support from the Spanish Ministry of Economy and Competitiveness (National R\&D Project DER2016-76053-R). We are very grateful for the valuable comments and suggestions offered by the Associate Editor and four anonymous referees.

Conflicts of Interest: The authors declare no conflicts of interest.

\section{References}

1. Arrazola-Vacas, M.; Hevia-Payá, J.; Rodríguez-Esteban, L. Qué factores ayudan a explicar la satisfacción con la Atención Primaria en España? Rev. Calid. Asist. 2015, 30, 226-236. [CrossRef] [PubMed]

2. Faezipour, M.; Ferreira, S. A system dynamics perspective of patient satisfaction in healthcare. Procedia Comput. Sci. 2013, 16, 148-156. [CrossRef]

3. Jaráiz, E.; Lagares, N.; Pereira, M. The components of patient satisfaction and their usefulness for hospital management. Rev. Española Cienc. Política 2013, 32, 161-181.

4. Pérez-Romero, S.; Gascón-Cánovas, J.; Salmerón-Martínez, D.; Parra-Hidalgo, P.; Monteagudo-Piqueras, O. Sociodemographic characteristics and geographic variability associated with patient satisfaction in Primary Care. Rev. Calid. Asist. 2016, 31, 300-308. [CrossRef]

5. Maesala, A.; Paul, J. Service quality, consumer satisfaction and loyalty in hospitals: Thinking for the future. J. Retail. Consum. Serv. 2018, 40, 261-269. [CrossRef]

6. Handayani, P.; Hidayanto, A.; Sandhyaduhita, P.; Kasiyan, D. Strategic hospital services quality analysis in Indonesia. Expert Syst. Appl. 2015, 42, 3067-3078. [CrossRef]

7. Aliman, N.; Mohamad, W. Linking Service Quality, Patients' Satisfaction and Behavioral Intentions: An Investigation on Private Healthcare in Malaysia. Procedia Soc. Behav. Sci. 2016, 224, 141-148. [CrossRef]

8. Vogus, T.; McClelland, L. When the customer is the patient: Lessons from healthcare research on patient satisfaction and service quality ratings. Hum. Resour. Manag. Rev. 2016, 26, 37-49. [CrossRef]

9. Correia, S.; Miranda, F. Calidad y satisfacción en el servicio de urgencias hospitalarias: Análisis de un hospital de la zona centro de Portugal. Investig. Eur. Dir. Econ. Empres. 2010, 16, 27-41. [CrossRef]

10. Yang, H.; Guo, X.; Wu, T. Exploring the influence of the online physician service delivery process on patient satisfaction. Decis. Support Syst. 2015, 78, 113-121. [CrossRef]

11. Numbeo. Europe: Health Care Index by Country 2019 Mid-Year. Available online: https://www.numbeo. com/health-care/rankings_by_country.jsp?title=2019-mid\&region=150 (accessed on 15 January 2019).

12. Koos, E. The Health of Regionsville; Columbia University Press: New York, NY, USA, 1954.

13. Donabedian, A. Evaluating the quality of medical care. Milbank Q. 1966, 44, 166-206. [CrossRef]

14. Li, M.; Lowrie, D.; Huang, C.; Lu, X.; Zhu, Y.; Wu, X.; Shayiti, M.; Tang, Q.; Yang, H.; Chen, S.; et al. Evaluating patient's perception of service quality at hospitals in nine Chinese cities by use of the ServQual scale. Asian Pac. J. Trop. Biomed. 2015, 5, 497-504. [CrossRef]

15. Pérez-Romero, S.; Gascón-Cánovas, J.; Salmerón-Martínez, D.; Parra-Hidalgo, P.; Monteagudo-Piqueras, O. Relevance of the socioeconomic and health context in patient satisfaction. Gac. Sanit. 2017, 31, 416-422. [CrossRef] [PubMed]

16. Rebull, J.; Castellà, M.; Pablo, A.; Vázquez, R.; Portoles, M.; Chanovas, M. Satisfacción de los usuarios de un servicio de urgencias: Comparación de resultados. Rev. Calid. Asist. 2003, 18, 286-290. [CrossRef]

17. Chang, C.; Tseng, T.; Woodside, A. Configural algorithms of patient satisfaction, participation in diagnostics, and treatment decisions' influences on hospital loyalty. J. Serv. Mark. 2013, 27, 91-103. [CrossRef]

18. Fernández-Martín, L.; Iglesias-de-Sena, H.; Fombellida-Velasco; Vicente-Torres, I.; Alonso-Sardón, M.; Mirón-Canelo, J. Patient satisfaction as a quality indicator in mental health. Rev. Calid. Asist. 2016, 31, 254-261. [CrossRef]

19. Bible, J.; Shau, D.; Kay, H.; Cheng, J.; Aaronson, O. Are Low Patient Satisfaction Scores Always Due to the Provider? Spine 2018, 43, 58-64. [CrossRef] 
20. Busse, R.; Klazinga, N.; Panteli, D.; Quentin, W. Improving Healthcare Quality in Europe: Characteristics, Effectiveness and Implementation of Different Strategies; European Observatory on Health Systems and Policies: Copenhagen, Denmark, 2019.

21. González, N.; Quintana, J.; Bilbao, A.; Esteban, C.; San Sebastián, J.; Sierra de la, E. Patient satisfaction in four hospitals of the Basque Health Service. Gac. Sanit. 2008, 22, 210-217. [CrossRef]

22. Fuente-Rodríguez, A.; Fernández-Lerones, M.; Hoyos-Valencia, Y.; León-Rodríguez, C.; Zuloaga-Mendiolea, C.; Ruíz-Garrido, M. Primary care urgent service. Study of patient perceived quality and satisfaction in the Altamira health (Spain) catchment area. Rev. Calid. Asist. 2009, 24, 109-114.

23. García-Lacalle, J.; Martin, E. Rural vs urban hospital performance in a competitive public health service. Soc. Sci. Med. 2010, 71, 1131-1140. [CrossRef]

24. Dávila, F.; Herrera, J.; Yasnó, D.; Forero, L.; Alvarado, M. Satisfaction according to health care insurance systems in an emergency department. Rev. Calid. Asist. 2017, 32, 89-96. [CrossRef] [PubMed]

25. Mohd, A.; Chakravarty, A. Patient satisfaction with services of the outpatient department. Med. J. Armed Forces India 2014, 70, 237-242. [CrossRef] [PubMed]

26. Parasuraman, A.; Zeithaml, V.; Berry, L. A conceptual model of service quality and its implications for future research. J. Mark. 1985, 49, 41-50. [CrossRef]

27. Murillo, C.; Saurina, C. Measurement of the importance of user satisfaction dimensions in healthcare provision. Gac. Sanit. 2013, 27, 304-309. [CrossRef]

28. Kitapci, O.; Akdogan, C.; Dortyol, I. The Impact of Service Quality Dimensions on Patient Satisfaction, Repurchase Intentions and Word-of-Mouth Communication in the Public Healthcare Industry. Procedia Soc. Behav. Sci. 2014, 148, 161-169. [CrossRef]

29. García-Alfanca, F.; Puig, A.; Galup, C.; Aguado, H.; Cerdá, I.; Guilabert, M.; Pérez-Jover, V.; Carrillo, I.; Mira, J. Patient Satisfaction with Pre-Hospital Emergency Services. A Qualitative Study Comparing Professionals' and Patients' Views. Int. J. Environ. Res. Public Health 2018, 15, 233. [CrossRef]

30. Amin, M.; Nasharuddin, S. Hospital service quality and its effects on patient satisfaction and behavioural intention. Clin. Gov. Int. J. 2013, 18, 238-254. [CrossRef]

31. Caminal, J. La medida de la satisfacción: Un instrumento de participación de la población en la mejora de la calidad de los servicios sanitarios. Rev. Calid. Asist. 2001, 16, 276-279. [CrossRef]

32. Serrano-Del-Rosal, R.; Galiano-Coronil, S.; Ranchal-Romero, J. Diseccionando la satisfacción de los usuarios con los servicios de atención hospitalaria del sistema sanitario público andaluz. Prax. Sociol. 2014, 18, 101-116.

33. Díaz, R. Satisfacción del paciente: Principal motor y centro de los servicios sanitarios. Rev. Calid. Asist. 2002, 17, 22-29. [CrossRef]

34. De Simone, S.; Planta, A.; Cicotto, G. The role of job satisfaction, work engagement, self-efficacy and agentic capacities on nurses' turnover intention and patient satisfaction. Appl. Nurs. Res. 2018, 39, 130-140. [CrossRef] [PubMed]

35. Draaper, M.; Cohen, P.; Buchan, H. Seeking consumer views: What use are results of hospital patient satisfaction surveys? Int. J. Qual. Health Care 2001, 13, 463-468. [CrossRef] [PubMed]

36. Pascoe, G. Patient satisfaction in primary health care: A literature review and analysis. Eval. Program Plan. 1983, 6, 185-210. [CrossRef]

37. Barrasa, J.; Aibar, C. Revisión sistemática de los estudios de la satisfacción realizados en España en el período 1986-2001. Rev. Calid. Asist. 2003, 18, 580-590. [CrossRef]

38. Drosos, D.; Tsotsolas, N.; Skordoulis, M.; Chalikias, M. Patient satisfaction analysis using a multi-criteria analysis method: The case of the NHS in Greece. Int. J. Prod. Qual. Manag. 2018, 25, 491-505. [CrossRef]

39. Purcarea, L.; Gheorghe, I.; Petrescu, C. The Assessment of Perceived Service Quality of Public Health Care Services in Romania Using the SERVQUAL Scale. Procedia Econ. Financ. 2013, 6, 573-585. [CrossRef]

40. Charles, V.; Kumar, M. Satisficing data envelopment analysis: An application to SERVQUAL efficiency. Measurement 2014, 51, 71-80. [CrossRef]

41. Al-Neyadi, H.; Abdallah, S.; Malik, M. Measuring patien's satisfaction of healhcare services in the UAE hospitals: Using SERVQUAL. Int. J. Healthc. Manag. 2018, 11, 96-105. [CrossRef]

42. Agosta, L.J. Patient satisfaction with nurse practitioner-delivered primary healtcare services. J. Am. Acad. Nurse Pract. 2009, 21, 610-617. [CrossRef] 
43. Aiken, L.; Sloane, D.; Ball, J.; Bruyneel, L.; Rafferty, A.; Griffiths, P. Patient satisfaction with hospital care and nurses in England: An observational study. BMJ Open 2018, 8, 1-8. [CrossRef]

44. Noro, I.; Roter, D.; Kurosawa, S.; Miura, Y.; Ishizaki, M. The impact of gender on medical visit communication and patient satisfaction within the Japanese primary care context. Patient Educ. Couns. 2018, 101, 227-232. [CrossRef] [PubMed]

45. Chang, M.; Alemán, M.; Cañizares, M.; Ibarra, A. Satisfacción de los pacientes con la atención médica. Rev. Cuba. Med. Gen. Integral 1999, 15, 541-547.

46. Morales, J.; Bonill, C.; Celdrán, M.; Morilla, J.; Martín, F.; Contreras, E.; San Alberto, M.; Castilla, J. Design and validation of a home care satisfaction questionnaire: SATISFAD. Gac. Sanit. 2007, 21, 106-113.

47. Huynh, H.; Sweeny, K.; Miller, T. Transformational leadership in primary care: Clinicians' patterned approaches to care predict patient satisfaction and health expectations. J. Health Psychol. 2018, 23, 743-753. [CrossRef] [PubMed]

48. Finefrock, D.; Patel, S.; Zodda, D.; Nyirenda, T.; Nierenberg, R.; Feldman, J.; Ogedegbe, C. Patient-Centered Communication Behaviors That Correlate With Higher Patient Satisfaction Scores. J. Patient Exp. 2018, 5, 231-235. [CrossRef] [PubMed]

49. Newson, E.; Lee, E.; Rossi, A.; Dusza, S.; Nehal, K. Modernizing the Mohs Surgery Consultation: Instituting a Video Module for Improved Patient Education and Satisfaction. Dermatol. Surg. 2018, 44, 778-784. [CrossRef]

50. Yeh, M.; Wu, S.; Tung, T. The relation between patient education, patient empowerment and patient satisfaction: A cross-sectional-comparison study. Appl. Nurs. Res. 2018, 39, 11-17. [CrossRef]

51. Fenton, J.; Jerant, A.; Bertakis, K.; Franks, P. The Cost of Satisfaction. A National Study of Patient Satisfaction, Health Care Utilization, Expenditures, and Mortality. Arch. Intern. Med. 2012, 172, 405-411. [CrossRef]

52. Mira, J.; Aranaz, J. La satisfacción del paciente como una medida del resultado de la atención sanitaria. Med. Clin. (Barc) 2000, 114, 26-33.

53. Ramírez-Sánchez, T.; Nájera-Aguilar, P.; Nigenda-López, G. Percepción de la calidad de la atención de los servicios de salud en México: Perspectiva de los usuarios. Salud Publica Mex. 1998, 40, 1-10. [CrossRef]

54. Añel-Rodríguez, R.; Cambero-Serrano, M.; Irurzun-Zuazabal, E. Análisis de las reclamaciones de pacientes en Atención Primaria: Una oportunidad para mejorar la seguridad clínica. Rev. Calid. Asist. 2015, 30, 220-225. [CrossRef] [PubMed]

55. Parra, P.; Bermejo, R.; Más, A.; Hidalgo, M.; Gomis, R.; Calle, E. Factors related to patient satisfaction with hospital emergency services. Gac. Sanit. 2012, 26, 159-165.

56. Taqdees, F.; Shahab, A.; Asma, S. Hospital healthcare service quality, patient satisfaction and loyalty. Int. J. Qual. Reliab. Manag. 2018, 35, 1194-1214.

57. Quintana, J.; González, N.; Bilbao, A.; Aizpuru, F.; Escobar, A.; Esteban, C.; San Sebastián, J.; De la Sierra, E.; Thompson, A. Predictors of patient satisfaction with hospital healh care. BMC Health Serv. Res. 2006, 6, 1-9. [CrossRef]

58. Valls, M.; Abad, E. Patient satisfaction in the Spanish National Health System. An. Sist. Sanit. Navar. 2018, 41, 309-320.

59. Bleich, S.; Ozaltin, E.; Murray, C. How does satisfaction with the health-care system relate to patient experience? Bull. World Health Organ. 2009, 87, 271-278. [CrossRef]

60. Thornton, R.; Nurse, N.; Snavely, L.; Hackett-Zahler, S.; Frank, K.; DiTomasso, R. Influences on patient satisfaction in healthcare centers: A semi-quantitative study over 5 years. BMC Health Serv. Res. 2017, 17, 1-9. [CrossRef]

61. Chaniotakis, I.; Lymperopoulos, C. Service quality effect on satisfaction and word of mouth in the health care industry. Manag. Serv. Qual. Int. J. 2009, 19, 229-242. [CrossRef]

62. Isik, O.; Tengilimoglu, D.; Akbolat, M. Measuring health care quality with the Servqual method: A comparison in public and private hospitals. Health MED 2011, 5, 1921-1930.

63. Ricci-Cabello, I.; Stevens, S.; Dalton, A.; Griffiiths, R.; Campbell, J.; Valderas, J. Identifying Primary Care Pathways from Quality of Care to Outcomes and Satisfaction Using Structural Equation Modeling. Health Serv. Res. 2018, 53, 430-449. [CrossRef]

64. Rigdon, E. Rethinking Partial Least Squares Path Modeling: In Praise of Simple Methods. Long Range Plan. 2012, 45, 341-358. [CrossRef]

65. Sarstedt, M.; Hair, J.; Ringle, C.; Thiele, K.; Gudergan, S. Estimation issues with PLS and CBSEM: Where the bias lies! J. Bus. Res. 2016, 69, 3998-4010. [CrossRef] 
66. Nitzl, C.; Chin, W. The case of partial least squares (PLS) path modeling in managerial accounting research. J. Manag. Control 2017, 28, 137-156. [CrossRef]

67. Sarstedt, M.; Ringle, C.; Hair, J. Partial least squares structural equation modeling. In Handbook of Market Research; Homburg, C., Klarmann, M., Vomberg, A., Eds.; Springer: Cham, Switzerland, 2017; pp. 1-40.

68. Becker, J.-M.; Rai, A.; Rigdon, E. Predictive valide and formative measurment in Structural Equation Modeling: Embracing practical relevance. In Proceedings of the 34th International Conference on Information System, Milan, Italy, 15-18 December 2013.

69. Spekle, R.; Verbeeten, F. The use of performance measurement systems in the public sector: Effects on performance. Manag. Acc. Res. 2014, 25, 131-146. [CrossRef]

70. Roldán, J.; Real, J.; Ceballos, S. Antecedents and consequences of knowledge management performance: The role of IT infrastructure. Intang. Cap. 2018, 14, 518-535. [CrossRef]

71. Rojo-Ramírez, A.; Ramírez-Orellana, A.; Burgos-Burgos, J.; Ruíz-Palomo, D. The moderating effects of family farms between innovation, information systems and training-learning over performance. In Entrepreneurship and Family Business Vitality—Surviving and Flourishing in the Long Term; Publishing, S.I., Ed.; Springer: Cham, Switzerland, 2019; pp. 205-231.

72. Hair, J.; Hult, G.; Ringle, C.; Sarstedt, M. A Primer on Partial Least Squares Structural Equation Modeling (PLS-SEM), 2nd ed.; Sage Publications: Thousand Oaks, CA, USA, 2017.

73. Hair, J.; Risher, J.; Sarstedt, M.; Ringle, C. When to use and how to report the results of PLS-SEM. Eur. Bus. Rev. 2019, 31, 2-24. [CrossRef]

74. Ringle, C.; Wende, S.; Becker, J. SmartPLS; SmartPLS GmbH: Bönningstedt, Germany, 2015.

75. Roldán, J.; Sánchez-Franco, M. Variance-based structural equation modeling: Guidelines for using partial least squares in information systems research. In Research Methodologies, Innovations and Philosophies in Software Systems Engineering and Information Systems; Mora, M., Steenkamp, A., Johnston, L., Gamon, J., Eds.; IGI Global: Hershey, PA, USA, 2012; pp. 193-221.

76. Hair, J.; Ringle, C.; Sarstedt, M. PLS-SEM: Indeed a Silver Bullet. J. Mark. Theory Pract. 2011, 19, $139-152$. [CrossRef]

77. Chin, X. The partial least squares approach to structural equation modeling. In Modern Methods for Business Research; Marcoulides, G., Ed.; Lawrence Erlbaum Associates: London, UK, 1998; pp. 295-336.

78. Hayes, A. Statistical mediation analysis in the new millennium. Commun. Monogr. 2009, 76, 408-420. [CrossRef]

79. Cepeda, G.; Nitzl, C.; Rodán, J. Mediation analyses in partial least squares structural equation modeling: Guidelines and empirical examples. In Partial Least Squares Path Modeling: Basic Concepts, Methodological Issues and Applications; Latan, H., Noonan, R., Eds.; Springer: Heidelberg, Germany, 2017; pp. 173-195.

80. Falk, R.; Miller, N. A Primer for Soft Modeling; University of Akron Press: Akron, OH, USA, 1992.

81. OECD. European Observatory on Health Systems and Policies; Spain: Country Health Profile 2017; State of Health in the EU, OECD Publishing: Paris, France; European Observatory on Health Systems and Policies: Brussels, Belgium, 2017. [CrossRef]

(C) 2019 by the authors. Licensee MDPI, Basel, Switzerland. This article is an open access article distributed under the terms and conditions of the Creative Commons Attribution (CC BY) license (http://creativecommons.org/licenses/by/4.0/). 